\title{
The Theme of Revenge in Rawi Hage's De Niro's Game (2006)
}

\author{
Fatima Zohra Khelif
}

Department of English language and Literature, Module: Arabic Texts in English, Faculty of Foreign Languages, University of Jordan, Jordan

Instructor: Prof. Yousef Abu Amerieh

\begin{abstract}
This extended paper is provided to explore the theme of revenge in Rawi Hage's De Niro's Game (2006). The acts of avenge have been a significant theme in several literary works along with themes of love and death, from Greek tragedies to European literature with the works of Shakespeare, to world literature with such works of Dostoevsky. Those writers are ideologically and historically different. They have examined the same subject [revenge] with similar 'passion, complexity and concern'. Even contemporary Arabic writers in Diaspora write such works that explore avenge. Rawi Hage, the Lebanese-Canadian writer, is amongst whose novels involve the theme of vengeance. The main concern of this paper is to find out how in such radical circumstances when power abused, where individuals and groups have been suffered from social injustice and unfairness of justice avenge becomes the only solution to take back justice and honor.
\end{abstract}

Keywords-Rawi Hage- De Niro's Game- revenge.

Rawi Hage was born in Beirut, Lebanon, and lived through nine years of the Lebanese civil war during the 1970s and 1980s. He immigrated to Canada in 1992 where he now lives in. His first novel, De Niro's Game (2006), won the IMPAC Dublin Literary Award for the best English-language book published anywhere in the world in a given year, and has either won or been shortlisted for seven other major awards and prizes, including the Scotiabank Giller Prize and the Governor General's Literary Award. his works includes also his second novel Cockroach (2008) was the winner of the Paragraphe Hugh MacLennan Prize for Fiction His third novel, Carnival(2012), told from the perspective of a taxi driver. His fourth novel, Beirut Hellfire Society (2018), was published in Canada in 2018 and other countries in 2019. His work has been translated into 30 languages. (Rawi Hage biography)

De Niro's Game starts in war-torn Beirut and ends in Paris, a novel that dramatized a journey of Bassam, ,a clever and nihilistic young man who becomes caught up in the violence of life in a city at war with itself". The novel is divided into three sections. The first two sections recount Bassam's life in Beirut and his attempts to make enough money through drug-dealing, theft, and armed robbery to escape Lebanon and get to Rome, a city that he portrays it "must be a good place to walk freely" (19). This novel depicts a vivid divided Beirut not only by the infamous „Green Line separating Christian East Beirut from Muslim West Beirut, but by militias, gangs, ethnic hostilities, and personal vendettas". it tells the story of two young men Bassam whose nickname (Al Pacino) and his friend George (De Niro) are "beggars and thieves, horny Arabs with curly hair and open shirts and Marlboro packs rolled in our sleeves, dropouts, ruthless nihilists with guns, bad breath, and long American jeans" (13). Bassam and George both know that in their war-torn city there are only two ways to live a life beyond mere subsistence: leave or join the militia. Bassam tries to leave, and George joins the Christian militia of Abou-Nahra, a man "into Christianity, money, and power" (51). The third section tells the story of Bassam in Paris. He knows that George's father, Claude Mani, is dead, but that his wife Genevieve and daughter Rhea would like to find George. Bassam travels to Paris where Genevieve and Rhea give him a place to stay, hiding the fact that George is underground. He knows that George ees father, who is Jewish, had been working for Mossad before his death and that George had begun working for them as well. However, Roland, a Mossad agent, has been monitoring George's family to find out what has happened to George, and he offers Bassam a Canadian visa in exchange for information. Bassam refused to become caught up again in a war he has gone to such lengths to escape, he destroys the visa and decides to go instead to Rome.

There are many ways in which De Niro's Game can be read: as a novel of trauma, a,commentary on the Lebanese Civil War", „a nihilistic 
manifesto", „a sophisticated exercise in style „and as a "refugee novel". In this extended paper, it is read as a revenge masterpiece that figures the story of Bassam who flees to Paris after taking his avenge. Thus the act of revenge plays a significant role in Rawi Hage $e^{\text {ee }}$ novels. Bassam risks his life and is forced to flee Lebanon because he takes revenge on Rambo.

Additionally, in an interview that was appeared in the Washington Post 2017, Nigel Beale says that Hage called his novel "an uncompromising look at a place in the conflict, from the inside, presented truly, with artistic merit." Immediately upon saying this, he expresses concern that it smacks too much of hubris. "What I mean is that only the artists talk about this war. No monuments were raised to commemorate it, too contentious," he says. "There's no consensus between Christians and Muslims on what happened. No truth commission. No one mentions it. People wanted to forget."

Specifically, the theme of revenge is not only a new concern of modern literature, it was the main theme since ancient times, in particular, the acts of avenge has been significant theme in several literary works along with themes of love and death, from Greek tragedies such those of Sophocles to European literature with the works of Shakespeare, mainly Hamlet, to world literature with such works of Dostoevsky. Those writers are ideologically and historically different. They have examined the same subject [revenge] with similar „passion, complexity and concern"e. Even contemporary Arabic writers in Diaspora write such works that explore avenge. Rawi Hage, the Lebanese-Canadian writer, is amongst whose novels involve the theme of vengeance. Particularly, his Cockroach (2008) highlights revenge clearly when cockroach took revenge on behalf of Shohreh, and De Niro "s Game (2006) is the main concern in this paper to explore the theme of revenge in.

Vengeance gives the writer a convincing mix of ingredients: vicious circumstances; moral issues for debate; a hazardous, passionate mix of disappointment and loss of agitated complaints. Accordingly, Hage's novels portray individuals "who have been marginalized and exiled both within and without the boundaries of their homeland. Their victimization and alienation are due to exile or war, as well as the castrating conditions of poverty, displacement, and social injustice. They become wandering prowlers, who aim through their actual and fictitious roaming[s] to exercise their sense of confinement in excluding and denigrating systems". (50) She deeply indulges that Hage's 'focus is on the individual search for justice (51). She adds: "his peripheralized characters challenge the forces that strip away their civil identities, refuse to be victimized, to capitulate or compromise their principles. They retain their voices and assert their individuality" (51).

The title significantly depicts the fatal game that based on Robert De Niro's 1978 movie The Deer Hunter: a film which recounts the story of two best friends Michael Cimino"es (played by Robert De Niro) who loses his best friend Nick (played by Christopher Walken) during a lethal Russian roulette game in the Vietnam War. The movie brings out a tale of friendship, violence, loss, love, and self-exploration. This is similar to the story of

Bassam"s loss of his best friend George playing this game. Bassam himself describes this violent game:

If I possessed the baccarat kind of gun instead of an automatic, would I play with my fate? Would I leave myself only one bullet and roll the barrel, as so many young men had in Beirut during the war, after watching the movie The Deer Hunter? Many had died playing De Niro's game. (234-235)

Interestingly, Bassam adopts the nickname $A l$ Pacino and he was obsessed with the game [the Russian roulette] while George adopts the nickname, De Niro. However, the novel in a way or another seems like a Hollywood movie. Abdel Nasser wrote that "the alternative identity of De Niro, for the careless way he takes chances with his life. Russian roulette symbolizes war-decreed choices and resolutions: "We all agreed to participate. It was our choice, we each spun our gun barrels, and we each had four chances out offive. We all acted out of our convictions, and out of passion"(232-3). (51).

The main factors that led to Bassam's avenge from his enemies or offenders because of his anger from the gangs, mafia and in particular the militia forces practices over feeble and poor people, because of his pain from persecution and discrimination that he experienced under the militia especially Rambo, so that he suffers humiliation. "Revenge is personal"... it "involves a particular emotional tone, pleasure at the suffering of another, while retribution either need involve no emotional tone or involves another one, namely pleasure at justice being done". (qt. in Ziebart 87). In his, The Virtues of Vengeance Peter French wrote: "the taking of revenge usually produces an emotional or psychological state in the avenger, a feeling of pleasure, a sense of accomplishment, a high". (qtd in Ziebart 108). These two quotes highlight the case of Bassam when he managed to take his avenge especially was accused as 
a diamond thief by Abou-Nahra and tortured by a powerful militiaman named Rambo. Bassam devises a plan to take his revenge from militiamen, Majalis, in so doing he requests the aid of his friend Joseph Chaiben. He planned to do the last operation before his leaving Beirut. Bassam met Joseph; he bought a gun from him and told him that he "had an idea for the last hit to generate more money". "What kind of operation? Asked Joseph". "Robbing the casino" (163). Joseph couldn't believe what Bassam want to do, he called him a crazy man and that he put his life under danger and risks with the monsters of the Majalis. Bassam replied:

"But what have the Majalis done for you, Joseph? I saw you on the barricades for weeks on end. You risked your life. And all these commanders are getting sports cars and chalets, filling their bank accounts. Look you can hardly even buy food for your mother and your little sister and brothers. Think, Joseph. The war will be over one day, and they will be walking around in Armani suits, and what will we have? Do you think they will say, oh yes, he was a good fighter for the Christian cause? Think about it. We can each get a good amount of cash". (163)

Then Bassam suddenly asked Joseph about a man named Rambo. Joseph said he knows him, and "he is an ars". The nickname ars, means god of war drawing back to Greek mythology, so it is symbolized how ugly and brutal Rambo was. When Joseph agreed, Bassam carried out the operation and punished Najib and he accompanies. Bassam began his second plan to notice Rambo and chase after him and where he lives. He searched all night chasing after Rambo's black BMW car. He sat on the top of the hill and watched the passing cars, till he captures Rambo's car. "I saw a BMW speeding up the hill. It was driven as if a drunk, in zigzags, like a donkey climbing uphill". (170) Hage sophistically describes how Bassam ran after the car: "I ran after the $B M W$, through the pine trees, through the moist hills, through the morning dew, pushing away the loose branches...A man opened the door...It was Rambo"(170171). The selected passages are highly witness how thirsty was Bassam to take his revenge from this monster as he called him seeking to restore his honor and dignity and he did not leave until Rambo's last breath: " I walked toward him, and when he heard my steps he looked back and pulled out his gun in slow motion. I stopped. I saw his face, and my heart started to beat with sounds of death and drums". (171) He remembered how much pain Rambo caused by his torture then he killed him: "My hands stretched forward, both of my index fingers squeezed the trigger, and I shot at him". "I shot him until he fell to the ground,

and the thickening fog passed us by and carried his last breath" (171).

Moreover, Bassames killing Rambo was his last avenge before leaving Beirut. Before he gave a lesson to Nadjib and he accompanies. He described the way he catches them after they hit him harmfully: "Then $I$ bounced back like a demon: I ran with the drive of a thousand vengeful gods, salivating sweet blood and poisonous promises like a mad hymen..." (99). Bassam hit the two giant men and took The little Najib to investigate who told him to do this. When Najib refused to talk, Bassam threat to kill him if he doesn"et, he started crying as he wet himself. However, Bassam told him to choose between his life by telling him who sent them or he will die. Najib resisted, however, Bassam said: "then to the rats!" (100-101). Najib felt fear and told him that De Niro sent them. Bassam punished Najib after this two times and the last one when he gets to the operation of robbing the casino.

Furthermore, Bassam became angry with his best friend, of his brother who stabbed to his back and took his lover: "I went back to the roof and thought of George. I had almost killed George, my childhood friend, my brother who stabbed me and kissed me and who kissed my lover long enough to leave me". (139) ; another scene is when Bassam warned the so-called Altahouna for his ill manners: "listen, I am just doing this as a favor... Respect is very important to me. I love respect, and I kill disrespect". (147) Bassam himself that he became a vengeful person: "soon I became vindictive". (149)

By the end of the novel, Bassam tells Rhea that George was his brother, and how George stabbed into his back. He tells about their crimes, about killing birds, and people he said:

Yes, I said, and I told her about killing Khalil, and about our money scams, and our silent quarrels, and about George joining the militia. I told her about Monsieur Laurent, and Nicole, and my torture... . I continued talking about the massacre at the camp. I described to her what George had told me about the lights, the dog, the birds, the cadavers that piled up and rotted, the axes, the rivers ofblood. ... I told her about the night her brother took me under the bridge. (272-273)

On that night, George tells Bassam that he has 
just returned from a massacre in which Abou-Nahra's militia, with the help of Israeli intelligence, exterminated a Palestinian refugee camp: the horrifying Sabra and Shatila Massacre of 1982. George was deeply traumatized by what he has done. De Niro and Al Pacino met for the last time before Bassam tried to escape to Paris in a ship from Beirut. "George was drunk and he wanted to take Bassam to the militia headquarters to arrest him and prevent him from leaving the country. He had his gun on him and asked Bassam to play the Russian roulette game with him for the last time: „He played with his gun. He filled it with three bullets and spun it. He smiled, and then said to me; I am giving you a chance" (p. 274). Bassam agreed, and when he pulled the trigger the bullet did not go off, but it went off when it was George e's turn. Bassam then carried his dead friend in his arms and buried him under the bridge. He never told anyone about it until his final encounter with Rhea". (D. Said Mostapha 38-39)

André Forget, a contributor to Bierut to Carnival City: Reading Rawi Hage (2019), writes that while "the revenge trope is one of the oldest in Western literature, Hage places it in a distinctly modern context and challenges his readers to take seriously the possibility that revenge might sometimes not only be justified but necessary". (103). The contributor adds that Hage has a hint and "careful understanding of how power is often abused by those who have it, Bassam"s refusal to take sides in the Lebanese Civil War is a testament to his deep rejection of the partisanship that tears his country apart, a rejection that shows a high degree of moral and political agency, but it eventually drives him from Lebanon" (ibid).

Thus, and to sum up, the personal avenge here seems the only solution to Bassam for restoring justice and his honor and dignity. Therefore, in such kinds of radical circumstances, where individuals and groups have been denied all access to systems of justice, revenge becomes one of the only avenues through which marginalized individuals can assert their right to justice and, by extension, their right to be treated as human. He kills Rambo to avenge his confinement and torture, he learns Najib a lesson and his two giant men from forces, he already killed his friend De Niro for two reasons, first by intercepting his way to make money off from the machine and the second because of love. This novel combines all the aspects of loss, inequalities, and social injustice that lead to the tendency of vengeance.

\section{REFERENCES}

[1] Abdel Nasser, Safaa. Shape-Shifting As a Quest for Liberation, Empowerment And Justice: Metamorphosis and
Therianthropy In Rawi Hage's Novels. "European Journal of English Language and Literature Studies” Vol.4, No.3, pp.49-62, April 2016 Zaibert,

[2] Dalia Said Mostafa (2011): Journeying through a Discourse of Violence: Elias Khoury's Yalo and Rawi Hage's De Niro's Game, Middle East Critique, 20:01, 21-45

[3] Forget, André. "The Vengeful Refugee: Justice and Violence in Cockroach". In Bierut to Carnival City: Reading Rawi Hage. Edited by Krzy sztof Majer. Published E-Book in. Brill | Rodopi: 2019. Online.

[4] Hage, Rawi. De Niro's Game. Hanover, N.H.: Steerforth Press, 2007_https://archive.org/details/denirosgame00hage (Accessed 16th/11/2019)

[5] Leo. Punishment and Revenge. "Law and Philosophy" 25: 81-118. Springer 2006

[6] Nigel Beal, "Book Review: De Niro"s Game by Rawi Hage” October 6, 2017. (Accessed 07 December 2019 http://www.nigelbeale.com/2017/10/book-review-deniros-game-by-rawi-hage/ 